Letícia Mayara Magnago', Marina Donária Chaves Arantes', Graziela Baptista Vidaurre', Jordão Cabral Moulin ${ }^{2+}$, Paulo Fernando Trugilho

\title{
ENERGY ESTIMATE AND CARBON STOCK IN SHORT-ROTATION EUCALYPTUS STANDS
}

Keywords:

Dry biomass

Carbon sequestration

Spacing

Irrigation

Histórico:

Recebido 01/08/2016

Aceito $25 / 11 / 2016$

Palavras chave:

Biomassa seca

Sequestro de carbono

Espaçamento Irrigação

\footnotetext{
${ }^{+}$Correspondência: jordao_cm@hotmail.com
}

ABSTRACT: The use of biomass as an alternative energy source has been gaining attention because of its energy characteristics and environmental contribution and because it is renewable in short production periods. The aim of the present study was to evaluate the biomass production and carbon sequestration of eucalyptus grown under different conditions. The basic density of the wood, stem volume with and without bark and dry biomass, accumulated carbon, assimilated carbon dioxide and estimated energy for each shoot component were determined for two hybrid clones of $E$. grandis $x E$. urophylla at 6 and 12 months of age, grown at different spacing in two different areas, one with and one without irrigation. The highest dry biomass and carbon accumulation values were observed for plants grown at smaller spacing and with irrigation. A significant effect of irrigation on the variables quantified was only observed for 12-month-old plants. The amount of assimilated $\mathrm{CO}_{2}$ in the stem, leaves and branches was higher for 12-monthold plants grown at larger spacing and with irrigation. The estimated energy of the stem increased with increased spacing. Bark was the shoot component least influenced by spacing and irrigation.

\section{ESTIMATIVA ENERGÉTICA E ESTOQUE DE CARBONO EM POVOAMENTOS DE EUCALIPTO DE CURTA ROTAÇÃO}

RESUMO: A utilização da biomassa como fonte de energia alternativa tem obtido destaque por suas características energéticas, contribuição ambiental e por ser fonte de energia renovável em curto período de produção. $O$ trabalho objetivou avaliar a produção da biomassa e sequestro de carbono de eucalipto em diferentes condições de crescimento. Foram determinadas a densidade básica da madeira, volume individual com e sem casca, biomassa seca, carbono acumulado, dióxido de carbono assimilado e estimativa energética dos componentes da parte aérea de dois clones do híbrido de $\mathrm{E}$. grandis $\times \mathrm{E}$. urophylla aos 6 e 12 meses de idade, em diferentes espaçamentos e provenientes de duas áreas, uma irrigada e outra não irrigada. Os maiores valores de biomassa seca e massa de carbono foram provenientes dos clones nos espaçamentos mais adensados e região irrigada. $O$ efeito da irrigação foi significativo nas variáveis estudadas apenas nos clones com 12 meses. A quantidade de $\mathrm{CO}_{2}$ assimilada no fuste, folha e galho foram maiores nos espaçamentos mais amplos e região irrigada dos clones com 12 meses. A estimativa energética do fuste aumentou com a ampliação do espaçamento. Entre os componentes arbóreos, a casca sofreu menor influência dos espaçamentos e irrigação.

' Federal University of Espirito Santo - Vitória, Espírito Santo, Brasil

2 Federal University of Lavras - Lavras, Minas Gerais, Brasil 


\section{INTRODUCTION}

The increase in global temperature that has been occurring in the last few decades due to natural or anthropogenic factors is known worldwide as global warming. This warming is characterised by increases in ocean and air temperatures caused by the accumulation of gases released into the atmosphere (LISE; LAAN, 20I5). This change in climate is mainly caused by the burning of fossil fuels (JOENSUU; SINKKO, 20I5). Carbon dioxide $\left(\mathrm{CO}_{2}\right)$, methane $\left(\mathrm{CH}_{4}\right)$ and nitrous oxide $\left(\mathrm{N}_{2} \mathrm{O}\right)$ released into the atmosphere are the main gases responsible for heat trapping at the Earth's surface, aggravating the greenhouse effect.

The concern of some countries regarding global climate changes has led to discussions about how to solve or mitigate gas emissions into the atmosphere. Some measures to decrease these gases have been proposed in recent meetings, and projects were created to help minimise the greenhouse effect and obtain environmental compliance credits. Some countries have implemented policies to decrease gases that affect the greenhouse (CHENG et al. 20I5).

The use of bioenergy is a strategy that can potentially reduce greenhouse gases (THORNLEY et al. 20I5). Energy sources originating from forest biomass are examples of bioenergy. A possible strategy to decrease global warming is to increase forested areas, which contribute significantly to the absorption of atmospheric $\mathrm{CO}_{2}$, converting it into raw material for forest-based industries (TRUGILHO et al. 2010). Biomass is the organic matter stored in ecosystems, and it is the main source of nutrients and the main resource responsible for atmospheric carbon flow (WINK, 2009). The carbon sequestration capacity of an ecosystem depends on its biomass, in which forests play an important role. Brazil's contribution to the reduction in atmospheric carbon dioxide is considerable due to the large amount of biomass of its vast forest areas, both native and planted.

Eucalyptus wood has raised the interest of forest producers because of its versatility, namely, its rapid growth and the quality of the wood. These factors may vary depending on growth conditions such as spacing and irrigation. The wood quality and production for energy purposes can also be affected by planting spacing and irrigation (WIMMER et al. 2009).

Several studies have been performed with the aim of promoting the adequate use of energy sources other than fossil fuels. Thus, the aim of the present study was to evaluate the effect of spacing and irrigation on the biomass production of eucalyptus trees of different ages and to evaluate their potential for carbon sequestration.

\section{MATERIALS AND METHODS}

The plant material originated from a eucalyptus stand located in the northeast region of the state of Espirito Santo (1949' I5" S and 4005'20" W) and was supplied by the Company Fibria Celulose S. A. (Aracruz unit, state of Espírito Santo). The predominant soils in the region are Red Yellow Dystrophic Latosols and Red and Yellow Podzols (INCAPER, 20I I). The climate is Aw and Am according to the Köppen climate classification system, characterised by rainy summers and dry winters, with an annual mean temperature of $23^{\circ} \mathrm{C}$.

Two hybrid clones (Clone A and Clone B) of Eucalyptus grandis $\mathrm{x}$ Eucalyptus urophylla were used. The plants were 6 and 12 months old. The clones were planted in two different areas of approximately two hectares each, one with and one without irrigation, at 5 different spacings: $3 \times 0.5,1.5 \times 2,3 \times 1,3 \times 2$ and $3 \times 3 \mathrm{~m}$. In all the trees of the plantations were measured the height and diameter at ground $1.3 \mathrm{~m}$, to represent the plantation population was decided to use three trees with the average diameter, in order to reduce extrapolations from the results, noting that there was little difference between árvroes the heights of each planting condition. Thus, for each region (irrigated and non-irrigated) and each spacing and age used three trees, totalling 120 trees ( 3 trees $\times 5$ spacings $\times 2$ clones $\times 2$ ages $\times 2$ irrigation treatments). In Table I it can be seen the diameter at breast height and the height of the three trees obtained in each planting condition for biomass quantification.

Irrigation was performed for the first time when the stand was 3 months old, at planting and then on 4 occasions following planting, up to 12 months. Topdressing was applied together with irrigation by the company. Topdressing in the non-irrigated area was performed during rainy periods or with wet soil. The rainfall varied between 0.01 and $0.22 \mathrm{~mm}$, with a mean of $0.12 \mathrm{~mm}$ (FIBRIA, 20I3).

The tree volume was determined using the Smalian method. Stem height was measured up to a minimum diameter of $2 \mathrm{~cm}$ for 6-month-old trees and $5 \mathrm{~cm}$ for 12-month-old trees, with bark. The stem and bark volume were determined by measuring the volume of stems with and without the bark. The difference between the two measurements was considered the bark volume. The volumes used were obtained from Moulin (2013) because the author studied the same Eucalyptus grandis x Eucalyptus urophylla hybrid clones.

After being felled, the trees were fully debarked, deleafed and debranched, and the weight of each tree component was measured. Samples of each component were collected for subsequent analyses. 
TABLE I Diameter at breast height and the height of the three trees of two different E. grandis $x$ E. urophylla hybrid clones with different ages grown at different spacings with or without irrigation.

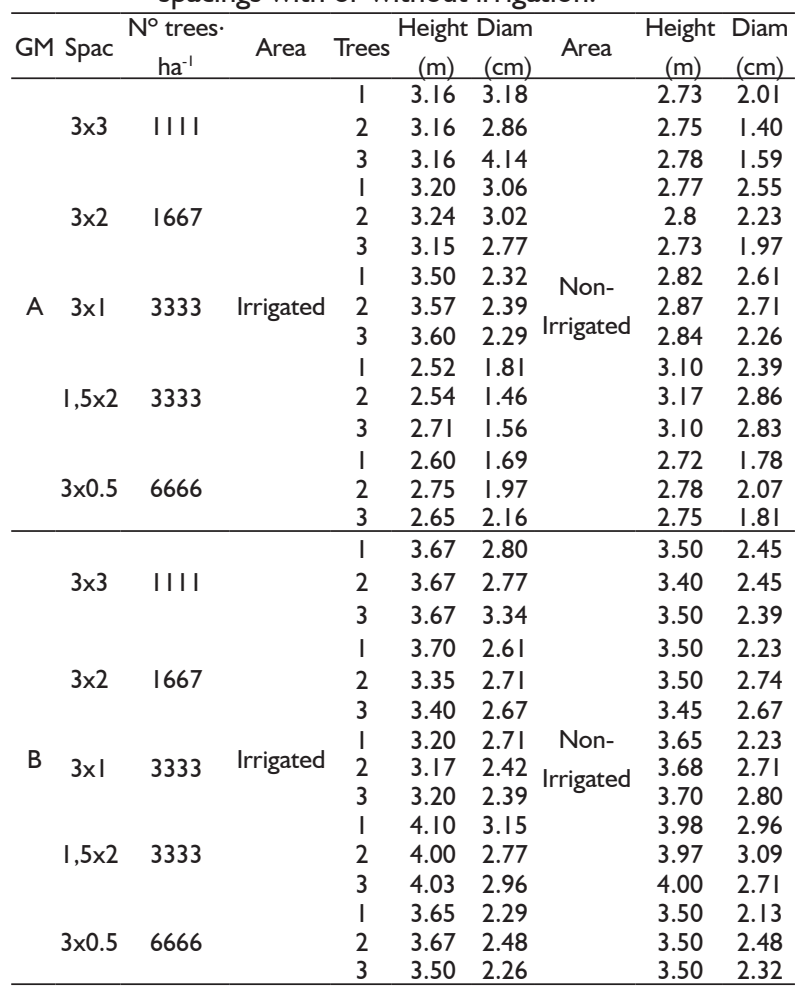

GM: genetic material; Spac: spacing; Diam: Diameter at the height of $1.3 \mathrm{~m}$ soil.

Leaf, branch and bark samples were weighed for fresh mass determination, dried in an oven at $100^{\circ} \mathrm{C}$ and weighed again to determine their dry mass. Dry samples were then ground.

To determine the basic density of the wood, 6 $25-\mathrm{cm}$-thick wood disks were collected from 6- and I2-month-old trees at $130 \mathrm{~m}$ from the ground (diameter at breast height - DBH) and at $0 \%, 25 \%, 50 \%, 75 \%$ and $100 \%$ of the stem commercial height. The wood basic density was determined according to norm NBR I 194 I (ABNT, 2003). Following determination of the wood basic density for each height, the average basic density weighted by volume was calculated using the volume of the wood disks [I], where BdWA=Average wood basic density weighted by volume $\left(\mathrm{g} \cdot \mathrm{cm}^{-3}\right) ; \mathrm{BdA}=$ Average wood basic density between the base $(0 \%)$ and $25 \%$, $25 \%$ and $50 \%, 50 \%$ and $75 \%$, and $75 \%$ and $100 \%$ stem height $\left(\mathrm{g} \cdot \mathrm{cm}^{-3}\right)$; and $\mathrm{V}=$ Stem volume between the base (0\%) and $25 \%, 25 \%$ and $50 \%, 50 \%$ and $75 \%$, and $75 \%$ and $100 \%$ stem height $\left(\mathrm{m}^{3}\right)$.

$$
\mathrm{BdWa}=\frac{\left(\mathrm{BdA}_{(0-25 \%)} \cdot \mathrm{V}_{(0-25 \%)}\right)+\ldots+\left(\mathrm{BdA}_{(75-100 \%)} \cdot \mathrm{V}_{(75-100 \%)}\right)}{\mathrm{V}_{(0-25 \%)}+\mathrm{V}_{(25-50 \%)}+\mathrm{V}_{(50-75 \%)}+\mathrm{V}_{(75-100 \%)}}
$$

The wood basic density values used were obtained from Moulin (2013) because the author used the same Eucalyptus grandis $x$ Eucalyptus urophylla hybrid clones. Stem dry biomass was calculated using the following equation (SOARES, 2006) [2], where: $\mathrm{DM}_{\mathrm{s}}=$ stem dry biomass $(\mathrm{kg}) ; \mathrm{V}=$ stem volume without bark $\left(\mathrm{m}^{3}\right)$; and BdWA = average stem wood basic density weighted by volume $\left(\mathrm{kg} \cdot \mathrm{m}^{-3}\right)$.

$\mathrm{DMs}=\mathrm{V} \cdot \mathrm{BdWa}$

The branch, leaf and bark dry biomasses were calculated using the equation [3], where: DM = total dry biomass $(\mathrm{kg})$; $\mathrm{FM}(\mathrm{a})=$ total fresh mass in the field $(\mathrm{kg})$; $\mathrm{DM}(\mathrm{b})=$ sample dry mass $(\mathrm{kg})$; and $\mathrm{FM}(\mathrm{c})=$ sample fresh mass $(\mathrm{kg})$.

$D M=(F M(a) \cdot D M(b)) \cdot F M(c)^{-1}$

Wood higher heating value $(\mathrm{HHV})$ determinations and elemental analyses were performed using composite samples of the disks collected at the different stem heights of each tree.

The HHV was determined according to norm NBR 8633/84 (ABNT, 1984) of the Brazilian Association of Technical Norms (Associação Brasileira de Normas Técnicas - ABNT), using a digital calorimeter, at the Laboratory of Biomass Energy of the Department of Forest and Wood Sciences of the Federal University of Espirito Santo (Universidade Federal do Espírito Santo - UFES).

Elemental analysis, i.e., determination of the concentrations of carbon (C), hydrogen $(H)$, nitrogen $(\mathrm{N})$, sulphur $(\mathrm{S})$ and oxygen $(\mathrm{O})$ by difference, was performed using $3 \mathrm{mg}$ dry mass aliquots of each sample using an elemental analyser. All the procedures described above were performed at the Laboratory of Elemental Analysis of the Federal University of Lavras (Universidade Federal de Lavras - UFLA).

The amount of heat produced by full combustion of each shoot component was calculated by multiplying the dry biomass $(\mathrm{kg})$ and the respective $\mathrm{HHV}\left(\mathrm{kcal} \cdot \mathrm{kg}^{-1}\right)$ as follows [4], where: EE = estimated energy (kcal); DM = dry biomass $(\mathrm{kg})$; and $\mathrm{HHV}=$ higher heating value.

$\mathrm{EE}=\mathrm{DM} \cdot \mathrm{HHV}$

After obtaining the dry biomass accumulation and carbon estimated energy of the trees harvested, initially held the mean of three trees each planting condition and then multiplied by the number of trees present in the respective hectare. 
An initial separate analysis of the two areas (with and without irrigation) was performed using a completely randomised experimental design with a $2 \times 2 \times 5$ factorial scheme $(2$ clones $\times 2$ ages $\times 5$ spacings), with a total of 20 treatments and 3 replicates per treatment. Subsequently, a joint analysis was performed considering the two areas. Because the interaction between the 4 tested factors was significant $(p<0.05)$, the factorial design was abandoned, and the means of the 40 treatments ( 2 areas $\times 2$ clones $\times 2$ ages $\times 5$ spacings) were compared using the ScottKnott test at $p<0.05$.

\section{RESULTS AND DISCUSSION}

The highest stem dry biomass (I5.72 odt $\cdot \mathrm{ha}^{-1}$ ) was observed for clone $\mathrm{B}$, at 12 months of age, grown at a I.5×2 $\mathrm{m}$ spacing with irrigation (Table 2). The stem dry biomass increased with decreasing spacing due to the higher number of individuals per hectare at smaller spacings. The stem dry biomass was higher with irrigation than without irrigation for the two clones and two plant ages.

TABLE 2 Mean dry biomass of the shoot components of two different E. grandis $\times$ E. urophylla hybrid clones with different ages grown at different spacings with or without irrigation.

\begin{tabular}{|c|c|c|c|c|c|c|c|}
\hline Clone & $\begin{array}{c}\text { Age } \\
\text { (months) }\end{array}$ & $\begin{array}{l}\text { Spacing } \\
(\mathrm{m})\end{array}$ & Area & $\begin{array}{c}\text { Stem } \\
\left(\text { odt } \cdot \text { ha }^{-1}\right)\end{array}$ & $\begin{array}{l}\text { Leaves } \\
\left.\text { (odt } \cdot \mathrm{ha}^{-1}\right)\end{array}$ & $\begin{array}{l}\text { Branches } \\
\left(\text { odt } \cdot h^{-1}\right)\end{array}$ & $\begin{array}{c}\text { Bark } \\
\left.\text { (odt } \cdot h a^{-1}\right)\end{array}$ \\
\hline \multirow{20}{*}{ A } & \multirow{10}{*}{6} & \multirow[b]{2}{*}{$3 \times 3$} & Irrigated & $0.83 \mathrm{j}$ & $1.29 \mathrm{~d}$ & $1.39 \mathrm{~d}$ & $0.21 \mathrm{f}$ \\
\hline & & & Non-irrigated & $0.42 \mathrm{j}$ & $0.70 \mathrm{~d}$ & $0.34 \mathrm{~d}$ & $0.08 \mathrm{f}$ \\
\hline & & \multirow{2}{*}{$3 \times 2$} & Irrigated & $1.05 \mathrm{j}$ & $1.17 \mathrm{~d}$ & $1.62 \mathrm{~d}$ & $0.18 \mathrm{f}$ \\
\hline & & & Non-irrigated & $0.79 \mathrm{j}$ & $0.87 \mathrm{~d}$ & $1.24 \mathrm{~d}$ & $0.15 \mathrm{f}$ \\
\hline & & \multirow{2}{*}{$3 \times 1$} & Irrigated & $1.50 \mathrm{i}$ & $1.02 \mathrm{~d}$ & $1.51 \mathrm{~d}$ & $0.27 \mathrm{f}$ \\
\hline & & & Non-irrigated & $1.53 \mathrm{i}$ & $1.16 \mathrm{~d}$ & $2.16 \mathrm{~d}$ & $0.28 \mathrm{f}$ \\
\hline & & \multirow{2}{*}{$1.5 \times 2$} & Irrigated & $\mathrm{I} .14 \mathrm{j}$ & $1.18 \mathrm{~d}$ & $2.08 \mathrm{~d}$ & $0.27 \mathrm{f}$ \\
\hline & & & Non-irrigated & $1.75 \mathrm{j}$ & $1.74 \mathrm{~d}$ & $2.07 \mathrm{~d}$ & $0.37 \mathrm{f}$ \\
\hline & & \multirow{2}{*}{$3 \times 0.5$} & Irrigated & $2.15 i$ & $1.26 \mathrm{~d}$ & $2.38 \mathrm{~d}$ & $0.29 \mathrm{f}$ \\
\hline & & & Non-irrigated & $0.97 \mathrm{i}$ & $0.99 \mathrm{~d}$ & $1.46 \mathrm{~d}$ & $0.21 \mathrm{f}$ \\
\hline & \multirow{10}{*}{12} & \multirow{2}{*}{$3 \times 3$} & Irrigated & $5.06 \mathrm{~g}$ & $3.23 \mathrm{a}$ & $5.96 \mathrm{a}$ & $1.06 \mathrm{e}$ \\
\hline & & & Non-irrigated & $2.42 \mathrm{i}$ & $1.54 \mathrm{c}$ & $3.51 \mathrm{c}$ & $0.5 \mathrm{If}$ \\
\hline & & \multirow{2}{*}{$3 \times 2$} & Irrigated & $7.26 f$ & $2.88 \mathrm{~b}$ & $6.93 \mathrm{a}$ & $1.11 \mathrm{~d}$ \\
\hline & & & Non-irrigated & $4.57 \mathrm{~g}$ & $2.44 \mathrm{~b}$ & $4.80 \mathrm{~b}$ & $1.20 \mathrm{~d}$ \\
\hline & & \multirow{2}{*}{$3 \times 1$} & Irrigated & $8.44 \mathrm{e}$ & $2.03 \mathrm{c}$ & $2.32 \mathrm{~d}$ & $1.32 \mathrm{~d}$ \\
\hline & & & Non-irrigated & $7.32 \mathrm{f}$ & $2.02 \mathrm{c}$ & $3.49 \mathrm{c}$ & $1.17 \mathrm{~d}$ \\
\hline & & \multirow{2}{*}{$1.5 \times 2$} & Irrigated & $7.12 \mathrm{f}$ & $1.92 \mathrm{c}$ & $4.52 c$ & $1.22 \mathrm{~d}$ \\
\hline & & & Non-irrigated & $9.17 \mathrm{~d}$ & $2.67 \mathrm{~b}$ & $5.09 \mathrm{~b}$ & $1.80 \mathrm{~b}$ \\
\hline & & \multirow{2}{*}{$3 \times 0.5$} & Irrigated & $6.71 \mathrm{f}$ & $1.22 \mathrm{~d}$ & $2.25 \mathrm{~d}$ & $1.06 \mathrm{e}$ \\
\hline & & & Non-irrigated & $3.50 \mathrm{~h}$ & $0.98 \mathrm{~d}$ & $1.68 \mathrm{~d}$ & $0.67 \mathrm{f}$ \\
\hline \multirow{20}{*}{ B } & \multirow{10}{*}{6} & \multirow{2}{*}{$3 \times 3$} & Irrigated & $0.90 \mathrm{j}$ & $1.06 \mathrm{~d}$ & $1.31 \mathrm{~d}$ & $0.36 \mathrm{f}$ \\
\hline & & & Non-irrigated & $0.55 \mathrm{j}$ & $0.64 \mathrm{~d}$ & $0.34 \mathrm{~d}$ & $0.15 \mathrm{f}$ \\
\hline & & \multirow{2}{*}{$3 \times 2$} & Irrigated & $0.95 j$ & $1.05 \mathrm{~d}$ & $1.43 \mathrm{~d}$ & $0.30 \mathrm{f}$ \\
\hline & & & Non-irrigated & $0.93 \mathrm{j}$ & $1.52 \mathrm{c}$ & $1.67 \mathrm{~d}$ & $0.21 \mathrm{f}$ \\
\hline & & \multirow{2}{*}{$3 \times 1$} & Irrigated & $1.68 \mathrm{i}$ & $1.20 \mathrm{~d}$ & $2.06 \mathrm{~d}$ & $0.35 \mathrm{f}$ \\
\hline & & & Non-irrigated & $1.78 \mathrm{i}$ & $1.39 \mathrm{~d}$ & $1.97 \mathrm{~d}$ & $0.38 \mathrm{f}$ \\
\hline & & \multirow{2}{*}{$1.5 \times 2$} & Irrigated & $2.34 \mathrm{i}$ & $1.89 \mathrm{c}$ & $2.37 \mathrm{~d}$ & $0.92 \mathrm{e}$ \\
\hline & & & Non-irrigated & $2.14 \mathrm{i}$ & $2.05 \mathrm{c}$ & $2.59 \mathrm{~d}$ & $0.44 \mathrm{f}$ \\
\hline & & \multirow{2}{*}{$3 \times 0.5$} & Irrigated & $2.53 \mathrm{i}$ & $1.09 \mathrm{~d}$ & $1.64 \mathrm{~d}$ & $0.44 \mathrm{f}$ \\
\hline & & & Non-irrigated & $1.32 \mathrm{j}$ & $0.77 \mathrm{~d}$ & $1.24 \mathrm{~d}$ & $0.28 \mathrm{f}$ \\
\hline & \multirow{10}{*}{12} & \multirow{2}{*}{$3 \times 3$} & Irrigated & $8.76 \mathrm{e}$ & $3.93 \mathrm{a}$ & $3.84 \mathrm{c}$ & $1.41 \mathrm{~d}$ \\
\hline & & & Non-irrigated & $5.02 \mathrm{~g}$ & $2.4 \mathrm{Ib}$ & $2.45 \mathrm{~d}$ & $0.88 \mathrm{e}$ \\
\hline & & \multirow{2}{*}{$3 \times 2$} & Irrigated & $10.82 c$ & $3.72 \mathrm{a}$ & $4.06 \mathrm{c}$ & $1.53 c$ \\
\hline & & & Non-irrigated & $6.61 \mathrm{f}$ & $2.90 \mathrm{~b}$ & $3.21 \mathrm{c}$ & $1.12 \mathrm{~d}$ \\
\hline & & \multirow{2}{*}{$3 \times 1$} & Irrigated & $10.08 c$ & $2.86 \mathrm{~b}$ & $5.20 \mathrm{~b}$ & $1.54 \mathrm{c}$ \\
\hline & & & Non-irrigated & $10.36 \mathrm{c}$ & $2.03 \mathrm{c}$ & $3.49 \mathrm{c}$ & $1.17 \mathrm{~d}$ \\
\hline & & \multirow{2}{*}{$1.5 \times 2$} & Irrigated & $15.72 \mathrm{a}$ & $3.70 \mathrm{a}$ & $3.87 c$ & $2.28 \mathrm{a}$ \\
\hline & & & Non-irrigated & 14.48 b & $3.40 \mathrm{a}$ & $2.78 \mathrm{~d}$ & $2.23 \mathrm{a}$ \\
\hline & & & Irrigated & $11.20 \mathrm{c}$ & $2.08 \mathrm{c}$ & $1.73 \mathrm{~d}$ & $1.59 \mathrm{c}$ \\
\hline & & & Non-irrigated & $5.48 \mathrm{~g}$ & $1.21 \mathrm{~d}$ & $1.14 \mathrm{~d}$ & $0.89 \mathrm{e}$ \\
\hline
\end{tabular}

Values followed by the same letter belong to the same group according to the Scott-Knott test at the $5 \%$ probability level.
The highest leaf dry biomass was observed for clone $B$, at 12 months of age, grown at $3 \times 3 \mathrm{~m}$ and $3 \times 2$ $\mathrm{m}$ spacings with irrigation and at a $1.5 \times 2 \mathrm{~m}$ spacing with or without irrigation (3.93, 3.72, 3.70 and 3.40 odt.ha- ${ }^{-1}$ ).

Although the number of trees per hectare was higher with smaller spacing, no significant differences in leaf and branch dry biomass were observed between spacing regimes for the 6-month-old plants. This pattern was due to more space being available for leaf and branch development; i.e., competition between these shoot components was low at this age. In the initial stage of tree stand development, a large part of the tree carbohydrates are allocated to the production of crown biomass, but over time, the crowns begin to compete for growing space, the trunk development increases, and the development of leaves and branches decreases (CALDEIRA et al.; 2000; SOARES et al.; 2006).

The highest bark dry biomass was observed for clone $B$, at 12 months of age, grown at a $1.5 \times 2 \mathrm{~m}$ spacing with or without irrigation (2.28 and 2.23 odt.ha ${ }^{-1}$, respectively).

The production of shoot dry biomass per tree, especially of stem biomass, was higher with larger spacing due to higher growth in diameter, whereas the biomass production per unit area was higher with smaller spacing due to the higher number of individuals (OLIVEIRA NETO, 2003).

Irrigation has a positive effect on plant growth, development and productivity, and its use is highly recommended for the cultivation of several species Carvalho et al. (2000). Santana et al. (2002) evaluated the biomass production of 78-month-old E. grandis and E. saligna in 5 areas in the state of São Paulo and observed higher productivity in areas with higher rainfall and lower water deficit ( 14 I odt.ha-1 hectare for the area with highest rainfall and lowest water deficit and II 0 odt $\cdot \mathrm{ha}^{-1}$ for the area with lowest rainfall and highest water deficit). The values reported by these authors were higher than those observed in the present study due to the age difference between the studied stands.

The mean stem dry biomass was higher for clone B (approximately $5.67 \mathrm{odt}^{\mathrm{h}} \mathrm{ha}^{-1}$ ) than for clone A (3.69 odt.ha-1). Alves (2007) studied stands of different Eucalyptus clones at 4.5 years of age and observed biomass accumulation in the following descending order: stem $>$ branches $>$ bark $>$ leaves. In the present study, the following descending order was observed: stem $>$ branches $>$ leaves $>$ bark. The lower bark biomass observed may be explained by the young age of the studied stands. The total shoot dry biomass (all shoot 
components) was 8.82 odt.ha- ${ }^{-1}$ for clone $A$ and I I.06 odt ha-I for clone B.

Significant differences in mean carbon accumulation were observed among the stem, leaves, branches and bark components. The highest mean carbon accumulation was observed for the stem of clone $B$, at 12 months of age, grown at a $1.5 \times 2 \mathrm{~m}$ spacing with irrigation (Table 3). Santana (2009) also observed higher carbon accumulation at smaller spacing, but this factor increased with increasing tree age at wider spacing.

The stem carbon accumulation was higher with than without irrigation in 12-month-old trees. Leaf carbon accumulation was not significantly different between the treatments with and without irrigation but was lower with smaller spacing for the 12-month-old trees. No significant differences in leaf carbon accumulation were observed at different spacings for the 6-month-old trees.

The greatest carbon accumulation in the branches was observed at the widest spacings and with irrigation

TABLE 3 Mean dry biomass of the shoot components of two different $E$. grandis $x E$. urophylla hybrid clones with different ages grown at different spacings with or without irrigation.

\begin{tabular}{|c|c|c|c|c|c|c|c|}
\hline Clone & $\begin{array}{c}\text { Age } \\
\text { (months) }\end{array}$ & $\begin{array}{l}\text { Spacing } \\
\text { (m) }\end{array}$ & Area & $\begin{array}{c}\text { Stem } \\
\left(\text { odt } \cdot h a^{-1}\right)\end{array}$ & $\begin{array}{l}\text { Leaves } \\
\left(\text { odt } \cdot \mathrm{ha}^{-1}\right)\end{array}$ & $\begin{array}{l}\text { Branches } \\
\left(\text { odt } \cdot h a^{-1}\right)\end{array}$ & $\begin{array}{c}\text { Bark } \\
\left.\text { (odt } \cdot \text { ha }^{-1}\right)\end{array}$ \\
\hline \multirow{20}{*}{ A } & \multirow{10}{*}{6} & \multirow[b]{2}{*}{$3 \times 3$} & Irrigated & $0.38 j$ & $0.65 \mathrm{~d}$ & $0.64 \mathrm{~d}$ & $0.09 \mathrm{f}$ \\
\hline & & & Non-irrigated & $0.19 \mathrm{j}$ & $0.35 \mathrm{~d}$ & $0.43 \mathrm{~d}$ & $0.03 \mathrm{f}$ \\
\hline & & \multirow{2}{*}{$3 \times 2$} & Irrigated & $0.46 \mathrm{j}$ & $0.58 \mathrm{~d}$ & $0.74 \mathrm{~d}$ & $0.08 \mathrm{f}$ \\
\hline & & & Non-irrigated & $0.36 \mathrm{j}$ & $0.42 \mathrm{~d}$ & $0.58 \mathrm{~d}$ & $0.07 \mathrm{f}$ \\
\hline & & \multirow{2}{*}{$3 \times 1$} & Irrigated & $0.67 i$ & $0.53 d$ & $0.70 \mathrm{~d}$ & $0.12 \mathrm{f}$ \\
\hline & & & Non-irrigated & $0.69 \mathrm{i}$ & $0.57 \mathrm{~d}$ & $0.10 \mathrm{~d}$ & $0.13 \mathrm{f}$ \\
\hline & & \multirow{2}{*}{$1.5 \times 2$} & Irrigated & $0.5 \mathrm{l} \mathrm{j}$ & $0.59 \mathrm{~d}$ & $0.95 \mathrm{~d}$ & $0.12 \mathrm{f}$ \\
\hline & & & Non-irrigated & $0.80 \mathrm{i}$ & $0.84 \mathrm{c}$ & $0.92 \mathrm{~d}$ & $0.16 \mathrm{f}$ \\
\hline & & \multirow{2}{*}{$3 \times 0.5$} & Irrigated & $0.95 \mathrm{i}$ & $0.65 \mathrm{~d}$ & $1.12 \mathrm{~d}$ & $0.13 \mathrm{f}$ \\
\hline & & & Non-irrigated & $0.44 j$ & $0.48 \mathrm{~d}$ & $0.67 \mathrm{~d}$ & $0.09 \mathrm{f}$ \\
\hline & \multirow{10}{*}{12} & \multirow[b]{2}{*}{$3 \times 3$} & Irrigated & $2.20 \mathrm{~g}$ & $1.63 \mathrm{a}$ & $2.83 \mathrm{a}$ & $0.48 \mathrm{e}$ \\
\hline & & & Non-irrigated & $1.14 \mathrm{i}$ & $0.78 \mathrm{c}$ & $1.60 \mathrm{c}$ & $0.23 \mathrm{f}$ \\
\hline & & \multirow[b]{2}{*}{$3 \times 2$} & Irrigated & $3.30 \mathrm{f}$ & $\mathrm{I} .47 \mathrm{~b}$ & $3.28 \mathrm{a}$ & $0.49 \mathrm{e}$ \\
\hline & & & Non-irrigated & $2.09 \mathrm{~g}$ & $1.23 \mathrm{~b}$ & $2.27 \mathrm{~b}$ & $0.54 \mathrm{~d}$ \\
\hline & & \multirow{2}{*}{$3 \times 1$} & Irrigated & $3.94 \mathrm{e}$ & $1.01 \mathrm{c}$ & $1.10 \mathrm{~d}$ & $0.57 \mathrm{~d}$ \\
\hline & & & Non-irrigated & $3.40 \mathrm{f}$ & $1.05 \mathrm{c}$ & $1.65 \mathrm{c}$ & $0.54 \mathrm{~d}$ \\
\hline & & \multirow{2}{*}{$1.5 \times 2$} & Irrigated & $3.42 \mathrm{f}$ & $0.98 c$ & $2.13 \mathrm{c}$ & $0.55 \mathrm{~d}$ \\
\hline & & & Non-irrigated & $4.23 \mathrm{~d}$ & $\mathrm{I} .41 \mathrm{~b}$ & $2.41 \mathrm{~b}$ & $0.8 \mathrm{Ib}$ \\
\hline & & \multirow{2}{*}{$3 \times 0.5$} & Irrigated & $3.18 \mathrm{f}$ & $0.62 d$ & $1.05 \mathrm{~d}$ & $0.47 \mathrm{e}$ \\
\hline & & & Non-irrigated & $1.62 \mathrm{~h}$ & $0.51 \mathrm{~d}$ & $0.78 \mathrm{~d}$ & $0.31 \mathrm{f}$ \\
\hline \multirow{20}{*}{ B } & \multirow{10}{*}{6} & \multirow{2}{*}{$3 \times 3$} & Irrigated & $0.40 \mathrm{j}$ & $0.54 \mathrm{~d}$ & $0.59 \mathrm{~d}$ & $0.15 \mathrm{f}$ \\
\hline & & & Non-irrigated & $0.25 \mathrm{j}$ & $0.32 \mathrm{~d}$ & $0.39 \mathrm{~d}$ & $0.07 \mathrm{f}$ \\
\hline & & \multirow{2}{*}{$3 \times 2$} & Irrigated & $0.43 \mathrm{j}$ & $0.54 \mathrm{~d}$ & $0.65 d$ & $0.12 \mathrm{f}$ \\
\hline & & & Non-irrigated & $0.42 \mathrm{j}$ & $0.77 \mathrm{c}$ & $0.76 \mathrm{~d}$ & $0.09 \mathrm{f}$ \\
\hline & & \multirow{2}{*}{$3 \times 1$} & Irrigated & $0.75 \mathrm{i}$ & $0.61 \mathrm{~d}$ & $0.95 \mathrm{~d}$ & $0.15 \mathrm{f}$ \\
\hline & & & Non-irrigated & $0.81 \mathrm{i}$ & $0.69 \mathrm{~d}$ & $0.91 \mathrm{~d}$ & $0.17 \mathrm{f}$ \\
\hline & & \multirow{2}{*}{$1.5 \times 2$} & Irrigated & $1.05 \mathrm{i}$ & $0.92 c$ & $1.08 \mathrm{~d}$ & $0.40 \mathrm{e}$ \\
\hline & & & Non-irrigated & $0.98 \mathrm{i}$ & $1.01 \mathrm{c}$ & $1.17 \mathrm{~d}$ & $0.19 f$ \\
\hline & & \multirow{2}{*}{$3 \times 0.5$} & Irrigated & $1.11 \mathrm{i}$ & $0.54 \mathrm{~d}$ & $0.77 d$ & $0.20 \mathrm{f}$ \\
\hline & & & Non-irrigated & $0.60 j$ & $0.38 \mathrm{~d}$ & $0.57 \mathrm{~d}$ & $0.13 \mathrm{f}$ \\
\hline & \multirow{10}{*}{12} & \multirow{2}{*}{$3 \times 3$} & Irrigated & $4.02 \mathrm{e}$ & $2.00 \mathrm{a}$ & $1.82 \mathrm{c}$ & $0.62 c$ \\
\hline & & & Non-irrigated & $2.36 \mathrm{~g}$ & $1.21 \mathrm{~b}$ & $1.14 \mathrm{~d}$ & $0.38 \mathrm{e}$ \\
\hline & & \multirow{2}{*}{$3 \times 2$} & Irrigated & $4.92 c$ & $1.87 \mathrm{a}$ & $1.90 \mathrm{c}$ & $0.66 \mathrm{c}$ \\
\hline & & & Non-irrigated & $2.99 \mathrm{f}$ & $\mathrm{I} .47 \mathrm{~b}$ & $1.50 \mathrm{c}$ & $0.49 \mathrm{e}$ \\
\hline & & \multirow{2}{*}{$3 \times 1$} & Irrigated & $4.72 \mathrm{c}$ & $\mathrm{I} .44 \mathrm{~b}$ & $2.44 \mathrm{~b}$ & $0.68 c$ \\
\hline & & & Non-irrigated & $4.78 c$ & $1.29 \mathrm{~b}$ & $1.62 \mathrm{c}$ & $0.80 \mathrm{~b}$ \\
\hline & & \multirow{2}{*}{$1.5 \times 2$} & Irrigated & $7.37 \mathrm{a}$ & $1.92 \mathrm{a}$ & $1.82 \mathrm{c}$ & $0.96 \mathrm{a}$ \\
\hline & & & Non-irrigated & $6.66 \mathrm{~b}$ & $1.79 \mathrm{a}$ & $1.31 \mathrm{~d}$ & $0.97 \mathrm{a}$ \\
\hline & & & Irrigated & $5.21 \mathrm{c}$ & $1.04 \mathrm{c}$ & $0.81 \mathrm{~d}$ & $0.68 c$ \\
\hline & & & Non-irrigated & $2.42 \mathrm{~g}$ & $0.63 d$ & $0.53 \mathrm{~d}$ & $0.39 \mathrm{e}$ \\
\hline
\end{tabular}

Values followed by the same letter belong to the same group according to the Scott-Knott test at the $5 \%$ probability level. for both of the plant ages. Bark carbon accumulation was little affected by irrigation and spacing but was almost 5 times higher for the 12-month-old than for the 6-monthold plants.

Overall, carbon accumulation was higher for clone B than for clone A (5.26 odt.ha' ${ }^{-1}$; Figure I). Carbon accumulation in trees was directly related to the amount of dry biomass because no pronounced variations were observed in carbon percentage. Gatto et al. (20II) studied the carbon stock in different shoot components of 8-year-old eucalyptus trees and observed that the stem accounted for, on average, $64.7 \%$ of the total shoot biomass. In the present study, the stem accounted for $50.1 \%$ of the total shoot biomass for clone B, which exhibited greater carbon accumulation. Santana et al. (2008) studied the biomass of eucalyptus with different ages and from different regions in Brazil and observed that the percentage of crown relative to the trunk decreased with increasing stand age. From 42 months of age up to 60 months of age, the crown percentage decreased more slowly, becoming even more stable from the sixth year on.

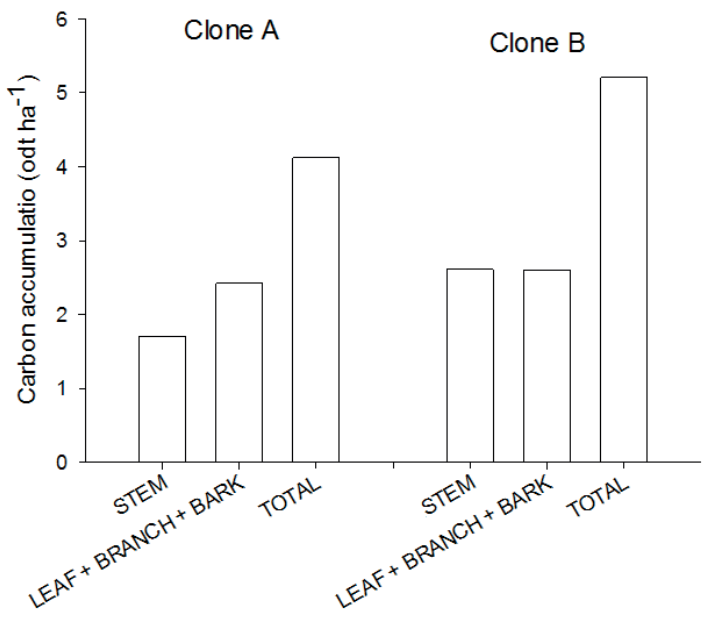

FIGURE I Carbon accumulation in different shoot components of two different hybrid clones of $E$. grandis $\mathrm{x}$ E. urophylla.

Carneiro et al. (2014) observed that carbon is essential for energy production, both in direct wood burning and charcoal production, because carbon is completely consumed in direct burning and is converted into fixed carbon, which is the main energy source stored in charcoal, during charcoal production. Materials with low carbon content should not be used for energy production because they have little biomass to sustain combustion.

One carbon dioxide $\left(\mathrm{CO}_{2}\right)$ molecule is assimilated for each stored carbon. Because the molar mass of $\mathrm{CO}_{2}$ is $44 \mathrm{~g} \cdot \mathrm{mol}^{-1}$ and that of carbon is $12 \mathrm{~g} \cdot \mathrm{mol}^{-1}, \mathrm{I}$ ton of 
accumulated carbon is estimated to correspond to 3.66 tons of assimilated $\mathrm{CO}_{2}$ (NUTTO et al.; 2002). The amounts of $\mathrm{CO}_{2}$ assimilated by $E$. grandis $\times E$. urophylla clones with different ages grown at different spacings, with or without irrigation.

The highest amount of $\mathrm{CO}_{2}$ assimilated in the stem was observed for the 12-month-old plants grown at a $1.5 \times 2 \mathrm{~m}$ spacing with irrigation (26.96 tons per hectare). The amount of $\mathrm{CO}_{2}$ assimilated in the stem was significantly higher for the 12 -month-old trees grown at $3 \times 3,3 \times 2$ and $3 \times 0.5 \mathrm{~m}$ spacings with irrigation.

The amount of assimilated $\mathrm{CO}_{2}$ in leaves decreased with decreasing spacing for the 12-month-old plants and the plants grown with irrigation. The highest amounts of assimilated $\mathrm{CO}_{2}$ in branches were observed for the 12-month-old plants grown at wider spacings ( $3 \times 3 \mathrm{~m}$ and $3 \times 2 \mathrm{~m}$ ) and with irrigation.

No significant effects of irrigation and spacing were observed on the amount of assimilated $\mathrm{CO}_{2}$ in the bark, although higher values were observed for the 12-month-old plants grown at a I.5×2 m spacing, with or without irrigation.

The $\mathrm{CO}_{2}$ assimilation was higher for clone $\mathrm{B}$ than for clone A. Clone $\mathrm{B}$ assimilated an average of 19 tons $\mathrm{CO}_{2}$ per hectare, with the stem accounting for $50.04 \%$ of this total (Figure 2). Clone A assimilated an average I 5.95 tons $\mathrm{CO}_{2}$ per hectare, $38.88 \%$ of which were in the stem. Plants can naturally directly transform inorganic substances that are part of material cycles, such as carbon, hydrogen and oxygen, into biomass, increasing the amount of material to sustain combustion and decreasing atmospheric $\mathrm{CO}_{2}$ concentrations (PACHECO; HELENE, 1990).

The mean estimated energy values differed significantly (Table 4). The highest stem estimated energy

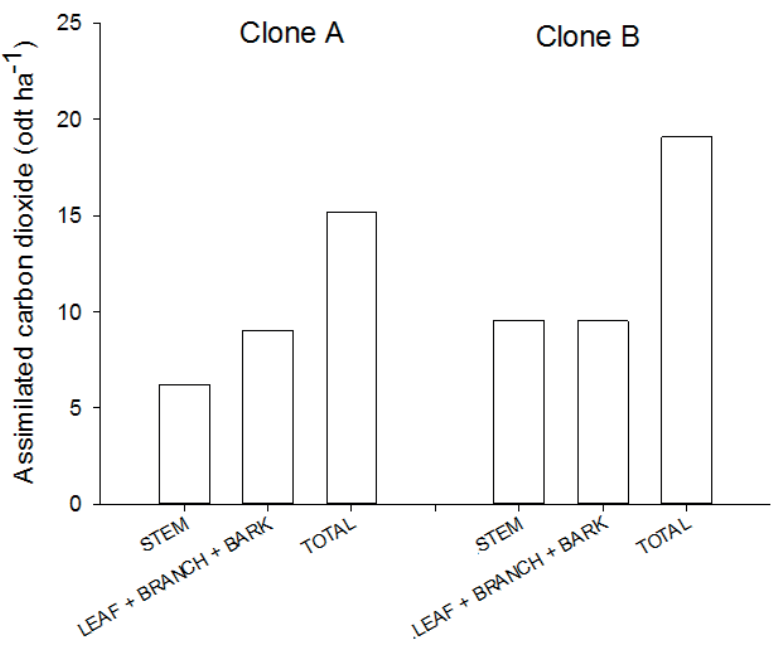

FIGURE 2 Assimilated carbon dioxide in different shoot components of two different hybrid clones of $E$. grandis $\times$ E. urophylla.
(70.73 gigacalories per hectare) was observed for clone $B$, at 12 months of age, grown at a $1.5 \times 2$ m spacing with irrigation.

The stem estimated energy increased with increased spacing, with a slight decrease at the $3 \times 0.5 \mathrm{~m}$ spacing. The effect of irrigation on the stem estimated energy was higher with larger spacing and for 12-monthold plants for the two clones.

The leaf, branch and bark estimated energy varied little with irrigation and spacing. The highest values were observed for the 12-month-old clones due to the higher biomass of these shoot components in these trees.

The mean estimated energy of the different shoot components is presented in Figure 3. Clone B exhibited higher stem estimated energy values (25.56 gigacalories per hectare, corresponding to $51.02 \%$ of the total shoot estimated energy) than clone A ( 16.67 tons per hectare, corresponding to $42.53 \%$ of the total shoot estimated energy). The estimated energy values for the remaining shoot components were similar for clones $A$ and $B$. However, clone B exhibited higher estimated energy for the whole shoot (50.I gigacalories per hectare) than clone A (39.67 gigacalories per hectare). The biomass energy potential is directly related to the amount of dry mass produced and its calorific value; i.e., materials with high calorific value and dry biomass will have high estimated energy, being ideal for use as energy sources.

\section{CONCLUSIONS}

Spacing and irrigation influenced the dry biomass production, accumulated carbon, assimilated carbon dioxide and estimated energy of the 12-month-old clones.

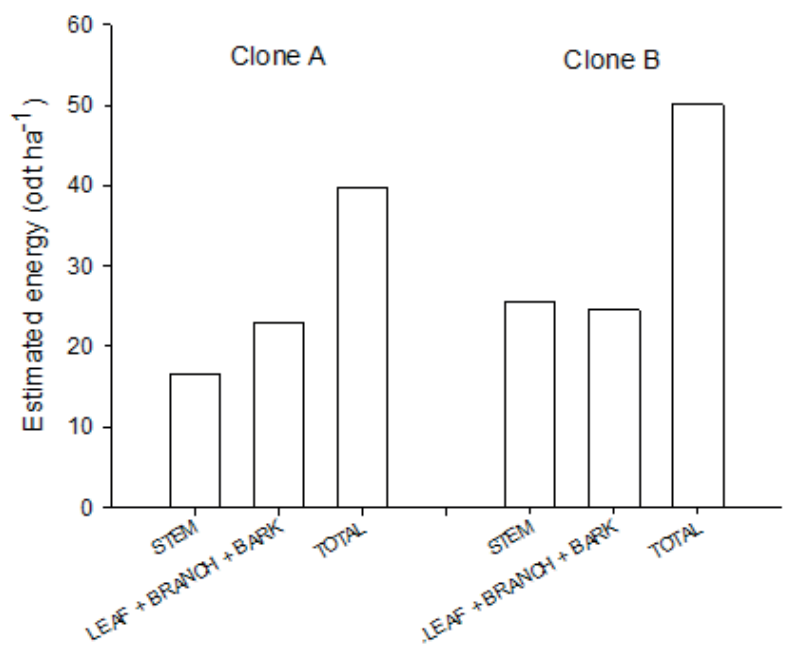

FIGURE 3 Estimated energy for different shoot components of two different hybrid clones of E. grandis $x$ E. urophylla. 
TABLE 4 Mean dry biomass of the shoot components of two different $\mathrm{E}$. grandis $\mathrm{x}$ E. urophylla hybrid clones with different ages grown at different spacings with or without irrigation.

\begin{tabular}{|c|c|c|c|c|c|c|c|}
\hline Clone & $\begin{array}{c}\text { Age } \\
\text { (months) }\end{array}$ & $\begin{array}{l}\text { Spacing } \\
(\mathrm{m})\end{array}$ & Area & $\begin{array}{c}\text { Stem } \\
\left(\text { odt } \cdot h a^{-1}\right)\end{array}$ & 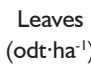 & 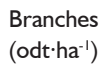 & $\begin{array}{c}\text { Bark } \\
\left(\text { odt } \cdot h a^{-1}\right)\end{array}$ \\
\hline \multirow{20}{*}{ A } & \multirow{10}{*}{6} & $3 \times 3$ & Irrigated & $3.86 \mathrm{j}$ & $6.26 \mathrm{~d}$ & $6.11 \mathrm{c}$ & $0.86 \mathrm{e}$ \\
\hline & & $3 \times 3$ & Non-irrigated & $2.47 \mathrm{j}$ & $3.37 \mathrm{~d}$ & $4.19 c$ & $0.33 \mathrm{e}$ \\
\hline & & \multirow{2}{*}{$3 \times 2$} & Irrigated & $4.78 j$ & $5.62 \mathrm{~d}$ & $7.12 \mathrm{c}$ & 0.77 e \\
\hline & & & Non-irrigated & $3.53 \mathrm{j}$ & $4.08 \mathrm{~d}$ & $5.52 \mathrm{~b}$ & $0.60 \mathrm{e}$ \\
\hline & & \multirow{2}{*}{$3 \times 1$} & Irrigated & $6.76 i$ & $4.98 \mathrm{~d}$ & $6.59 c$ & $1.10 \mathrm{e}$ \\
\hline & & & Non-irrigated & $7.00 \mathrm{i}$ & $5.37 \mathrm{~d}$ & $9.47 \mathrm{c}$ & $1.16 \mathrm{e}$ \\
\hline & & \multirow{2}{*}{$1.5 \times 2$} & Irrigated & $5.07 \mathrm{j}$ & $5.59 \mathrm{~d}$ & $9.09 \mathrm{c}$ & $1.10 \mathrm{e}$ \\
\hline & & & Non-irrigated & $7.89 \mathrm{i}$ & $8.14 \mathrm{c}$ & $9.06 \mathrm{c}$ & $1.50 \mathrm{e}$ \\
\hline & & \multirow{2}{*}{$3 \times 0.5$} & Irrigated & $9.46 \mathrm{i}$ & $6.04 \mathrm{~d}$ & $10.41 \mathrm{c}$ & $1.16 \mathrm{e}$ \\
\hline & & & Non-irrigated & $4.45 \mathrm{i}$ & $4.60 \mathrm{~d}$ & $6.39 c$ & $0.84 \mathrm{e}$ \\
\hline & \multirow{10}{*}{12} & \multirow{2}{*}{$3 \times 3$} & Irrigated & $23.23 \mathrm{~g}$ & $15.82 \mathrm{a}$ & $26.06 \mathrm{a}$ & $4.30 \mathrm{~d}$ \\
\hline & & & Non-irrigated & $10.98 i$ & $7.40 \mathrm{c}$ & I5.74 b & $2.10 \mathrm{e}$ \\
\hline & & \multirow{2}{*}{$3 \times 2$} & Irrigated & $32.50 \mathrm{f}$ & $13.90 \mathrm{~b}$ & $30.76 \mathrm{a}$ & $4.65 \mathrm{~d}$ \\
\hline & & & Non-irrigated & $20.62 \mathrm{~g}$ & $11.53 \mathrm{~b}$ & $21.32 \mathrm{a}$ & $4.92 \mathrm{~d}$ \\
\hline & & \multirow{2}{*}{$3 \times 1$} & Irrigated & $38.32 \mathrm{e}$ & $9.88 \mathrm{c}$ & $10.09 c$ & $5.35 \mathrm{c}$ \\
\hline & & & Non-irrigated & $32.91 \mathrm{f}$ & $9.43 \mathrm{c}$ & I5.42 b & $4.77 \mathrm{~d}$ \\
\hline & & \multirow{2}{*}{$1.5 \times 2$} & Irrigated & $32.33 \mathrm{f}$ & $9.16 \mathrm{c}$ & $20.10 \mathrm{~b}$ & $5.00 \mathrm{~d}$ \\
\hline & & & Non-irrigated & $41.21 \mathrm{~d}$ & $12.59 \mathrm{~b}$ & $22.55 \mathrm{a}$ & $7.31 \mathrm{~b}$ \\
\hline & & \multirow{2}{*}{$3 \times 0.5$} & Irrigated & $30.07 f$ & $5.85 \mathrm{~d}$ & $10.04 c$ & $4.26 \mathrm{~d}$ \\
\hline & & & Non-irrigated & $15.65 \mathrm{~h}$ & $4.57 \mathrm{~d}$ & $7.49 c$ & $2.73 \mathrm{e}$ \\
\hline \multirow{20}{*}{ B } & \multirow{10}{*}{6} & \multirow{2}{*}{$3 \times 3$} & Irrigated & $4.10 \mathrm{j}$ & $5.16 \mathrm{~d}$ & $5.77 \mathrm{c}$ & $1.46 \mathrm{e}$ \\
\hline & & & Non-irrigated & $2.47 \mathrm{j}$ & $3.05 \mathrm{~d}$ & $3.72 \mathrm{c}$ & $0.63 \mathrm{e}$ \\
\hline & & \multirow{2}{*}{$3 \times 2$} & Irrigated & $4.34 \mathrm{j}$ & $5.09 \mathrm{~d}$ & $6.28 c$ & $1.19 \mathrm{e}$ \\
\hline & & & Non-irrigated & $4.11 \mathrm{j}$ & $7.19 \mathrm{c}$ & $7.38 \mathrm{c}$ & $0.85 \mathrm{e}$ \\
\hline & & \multirow{2}{*}{$3 \times 1$} & Irrigated & $7.71 \mathrm{i}$ & $5.80 \mathrm{~d}$ & $8.98 \mathrm{c}$ & $1.41 \mathrm{e}$ \\
\hline & & & Non-irrigated & $7.98 \mathrm{i}$ & $6.50 \mathrm{~d}$ & $8.61 \mathrm{c}$ & $1.53 \mathrm{e}$ \\
\hline & & \multirow{2}{*}{$1.5 \times 2$} & Irrigated & $10.23 \mathrm{i}$ & $9.13 \mathrm{c}$ & $10.45 c$ & $3.77 \mathrm{~d}$ \\
\hline & & & Non-irrigated & $9.48 \mathrm{i}$ & $9.78 \mathrm{c}$ & $11.24 \mathrm{c}$ & $1.80 \mathrm{e}$ \\
\hline & & \multirow{2}{*}{$3 \times 0.5$} & Irrigated & $11.29 \mathrm{i}$ & $5.20 \mathrm{~d}$ & $7.30 \mathrm{c}$ & $1.78 \mathrm{e}$ \\
\hline & & & Non-irrigated & $6.02 j$ & $3.60 \mathrm{~d}$ & $5.43 c$ & $1.14 \mathrm{e}$ \\
\hline & \multirow{10}{*}{12} & \multirow{2}{*}{$3 \times 3$} & Irrigated & $39.84 \mathrm{~d}$ & $18.98 \mathrm{a}$ & $16.88 \mathrm{~b}$ & $5.75 \mathrm{c}$ \\
\hline & & & Non-irrigated & $22.43 \mathrm{~g}$ & $11.49 \mathrm{~b}$ & $10.88 c$ & $3.60 \mathrm{~d}$ \\
\hline & & \multirow{2}{*}{$3 \times 2$} & Irrigated & $49.04 c$ & $18.02 \mathrm{a}$ & $17.93 \mathrm{~b}$ & $6.11 \mathrm{c}$ \\
\hline & & & Non-irrigated & $29.55 \mathrm{f}$ & $13.78 \mathrm{~b}$ & $14.30 \mathrm{~b}$ & $4.56 \mathrm{~d}$ \\
\hline & & \multirow{2}{*}{$3 \times 1$} & Irrigated & $45.96 c$ & $13.83 \mathrm{~b}$ & $22.65 \mathrm{a}$ & $6.20 \mathrm{c}$ \\
\hline & & & Non-irrigated & $46.53 c$ & $11.99 \mathrm{~b}$ & I5.40 b & $7.49 \mathrm{~b}$ \\
\hline & & \multirow{2}{*}{$1.5 \times 2$} & Irrigated & $70.73 \mathrm{a}$ & $17.94 \mathrm{a}$ & $17.12 \mathrm{~b}$ & $9.31 \mathrm{a}$ \\
\hline & & & Non-irrigated & $64.78 b$ & $16.16 \mathrm{a}$ & $12.40 \mathrm{c}$ & $9.13 \mathrm{a}$ \\
\hline & & \multirow{2}{*}{$3 \times 0.5$} & Irrigated & $50.58 c$ & $9.99 \mathrm{c}$ & $7.70 \mathrm{c}$ & $6.5 \mathrm{I} \mathrm{b}$ \\
\hline & & & Non-irrigated & $24.53 \mathrm{~g}$ & $5.71 \mathrm{~d}$ & $5.05 c$ & $3.58 \mathrm{~d}$ \\
\hline
\end{tabular}

Values followed by the same letter belong to the same group according to the Scott-Knott test at the $5 \%$ probability level.

No significant effect of irrigation on the studied variables was observed for the 6-month-old plants, but a significant effect was observed for the 12-month-old plants.

The stem dry biomass and carbon accumulation were higher at smaller spacings and with irrigation. The dry biomass of the remaining shoot components varied little with spacing and irrigation.

Leaf carbon accumulation was higher with wider spacings for 12-month-old plants. Branch carbon accumulation was higher at wider spacings and with irrigation for the two plant ages. Irrigation and spacing had little effect on bark carbon accumulation.

The amounts of assimilated $\mathrm{CO}_{2}$ in the stem, leaves and branches were higher for I2-month-old plants grown at wider spacings and with irrigation. No effects of irrigation and spacing were observed on the amount of assimilated $\mathrm{CO}_{2}$ in the bark.

The stem estimated energy increased with increased spacing. The mean estimated energy of the leaves, branches and bark varied little with irrigation and spacing.

\section{REFERENCES}

ALVES, A.M.C. Quantificação da produção de biomassa e do teor de carbono fixado por clones de eucalipto, no pólo gesseiro do Araripe - PE. 2007. 62 f. Dissertação (Mestrado em Ciências Florestais) - Universidade Federal Rural de Pernambuco, Recife, 2007.

ASSOCIAÇÃO BRASILEIRA DE NORMAS TÉCNICAS. NBR | | 94 |: madeira: determinação da densidade básica. Rio de Janeiro, 2003. 6 p.

ASSOCIAÇÃO BRASILEIRA DE NORMAS TÉCNICAS. NBR 8633:carvão vegetal: determinação do poder calorífico. Rio de Janeiro, 1984. 12 p.

CALDEIRA, M. V. W.; SCHUMACHER, M. V.; TEDESCO, N.; PEREIRA, J.C.; SANTOS, E. M. dos. Produção de biomassa em uma procedência australiana de Acacia mearnsii de Wild., plantada no Sul do Brasil. Revista Árvore, Viçosa, v. 24, n. 2, p. 20I-206, 2000.

CARNEIRO, A. de C. O.; CASTRO, A. F. N. M.; CASTRO, R. V. O.; SANTOS, R. C. dos.; FERREIRA, L. P.; DAMÁSIO, R. A. P.; VITAL, B. R. Potencial energético da madeira de Eucalyptus sp. em função da idade e de diferentes materiais genéticos. Revista Árvore, Viçosa, v. 38, n. 2, p. 375-38I, 2014.

CARVALHO, A. J. C., MARTINS, D. P. MONERRAT, P. H., BERNARDO, S. Adubação nitrogenada e irrigação no maracujazeiro - amarelo. i. e qualidade dos frutos. Pesquisa Agropecuária Brasileira, v.35, n.6, p. I I0I-I I08, 2000.

CHENG, B.; Dai, H.; WANG, P.; ZHAO, D.; MASUI, T. Impacts of carbon trading scheme on air pollutant emissions in Guangdong Province of China. Energy for Sustainable Development, v. 27, p. I74-185, 2015.

FIBRIA. Produção de biomassa energética em diferentes espaçamentos, manejos e culturas: Eucalipto. Dados de análise interno da empresa Fibria (dados enviados por email), 2013.

GATTO, A.; BARROS, N. D. de.; SILVA, I. R. da; LEITE, H. G.; VILLANI, E. M. de. A. Estoque de carbono na biomassa de plantações de eucalipto na região centro-leste do estado de Minas Gerais. Revista Árvore, Viçosa, v. 35, n. 4, p. 895-905, 2011 .

INCAPER. Programa de Assitência Técnica e Extensão Rural Proater 20II-20I3. 20II. I5p.

JOENSUU, K.; SINKKO, T. Environmental sustainability and improvement options for agribiomass chains: Straw and turnip rape. Biomass and Bioenergy, v. 83, p. I-7, 2015.

LISE, W.; LAAN, J.V.D. Investment needs for climate change adaptation measures of electricity power plants in the EU. Energy for Sustainable Development, v. 28, p. 10-20, 2015. 
MOULIN, J. C. Produção de madeira de eucalipto de curta rotação em povoamentos adensados para energia. 2013. 6I f. Dissertação (Mestrado em Ciências Florestais) - Universidade Federal do Espírito Santo, Jerônimo Monteiro. 2013.

NUTTO, L.; WATLZAWICK, L.F.; GRAMMEL, R.; FENNER, P.T. O mercado internacional de $\mathrm{CO}_{2}$ : o impacto das florestas naturais e das plantações. In C.R. Sanquetta et al. (Ed.). As florestas e o carbono, p. 89-108, 2002.

OLIVEIRA NETO, S. N. et al. Produção e distribuição de biomassa em Eucalyptus camaldulensis Dehn. em resposta à adubação e ao espaçamento. Revista Árvore, Viçosa, v. 27, n. I. p. 15-23, 2003.

PACHECO, M. R. P. dos S.; HELENE, M. E. M. Atmosfera, fluxos de carbono e fertilização por $\mathrm{CO}_{2}$. Estudos avançados, vol.4, n.9, p. 204-220. 1990.

SANTANA, R. C. et al. Estimativa de biomassa de plantios de eucalipto no Brasil. Revista Árvore, Viçosa, v. 32, n. 4, p.697-706, 2008.

SANTANA, R. C.; BARROS, N.F.; NEVES, J.C.L. Eficiência nutricional e sustentabilidade da produção em procedências de Eucalyptus grandis e Eucalyptus saligna em sítios florestais do estado de São Paulo. Revista Árvore, Viçosa, v. 26, n. 4, p. 447-457, 2002.
SANTANA, Wilma Michele. Crescimento, produção e propriedades da madeira de um clone de Eucalyptus grandis e $E$. urophylla com enfoque energético. 2009. 9l f. Dissertação (Mestrado em Ciência e Tecnologia da Madeira) - Universidade Federal de Lavras, Lavras, 2009.

SOARES, C. P. B.; PAUlA NETO, F. de; SOUZA, A. L. de. Dendrometria e inventário florestal. Viçosa, $M G$, ed: UFV, 2006. 276p.

THORNLEY, P.; GILBERT, P.; SHACKLEY, S.; HAMMOND, J. Maximizing the greenhouse gas reductions from biomass: The role of life cycle assessment. Biomass and bioenergy, v. 81 , p. $35-43,2015$.

TRUGILHO, P.F.; ARANTES, M.D.C.; PÁDUA, F.A.; ALMADO, R.P.; BALIZA A.E.R. Estimate of fixed carbon in the wood of a hybrid clone of Eucalyptus urophylla and Eucalyptus grandis. Cerne, v. 16, p. 33-40, 2010.

WIMMER, R.; EVANS, R.; DOWNES, G.M.; RASMUSSEN, G.; FRENCH, J. Direct effects of wood characteristics on pulp and handsheet properties of Eucalyptus globulus. Holzforschung, v. 56, p. 244-252, 2002.

WINK, C. Estoque de carbono em plantações de Eucalyptus sp. implantados em campo nativo. 2009. I30p. Dissertação (Mestrado em Ciências Florestais) - Universidade Federal de Santa Maria, Santa Maria, RS, 2009. 